\title{
Expository Aspects of Snuhi Tail Preparation
}

\author{
Research Article
}

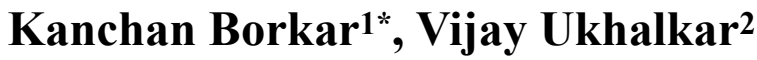

\section{Ph.D Scholar, 2. Professor and HOD, Department of Shalya Tantra,}

Government Ayurveda College, Nanded. India.

\begin{abstract}
Snuhi plant is a very important therapeutic approaches in Shalyatantra branch among Ashtang Ayurveda with less number of medicinal formulation. The utilization of Snuhi stem for Snuhi Tail preparation contributes towards the management of varicose veins. The Snuhi Tail is used as Abhyanga (Local application) for varicose vein which is supportive mode of management for varicose veins. The preparation of Snuhi Tail and its pharmaceutical analysis is discussed in present research article. The expository review has been made by different samples of Snuhi Tail which was prepared with same materials and methodologies at interval of one year.
\end{abstract}

Key Words: Varicose veins, Snuhi Tail, Snuhi Stem, Tila Tail, Abhyanga.

\section{Introduction}

Snuhi plant contributes evidence based role of master key in the form of minimum access surgery (Anushastra) for the diseases which are not easily curable. As reviewing Ashtang Ayurveda literature, use of Snuhi plant is described with less number of medicinal formulation. In current scenario, use of Snuhi plant in the form of Ksheera (latex) is at peak level in Shalyatantra practices while other useful part of Snuhi are rarely using even if other part also acts effectively. The utilization of Snuhi stem for Snuhi Tail preparation which contributes acceptability, suitability and stability with disease palliative efficacy towards the management of varicose veins.

Snuhi Tail is helpful in patients of varicose veins to increase quality life of patient. External use of Snuhi Tail in the form of Abhyanaga at initial stage of disease may avoid probable complications of disease like deep vein thrombosis, lipodermatosclerosis, formation of varicose ulcer etc. Varicosity is the penalty against gravity.(1) It is characterized by tortuosity, dilatation, elongation, sacculation of veins. It is commonly observed in oesophagus (Oesophageal varices), pampiniform plexus (Vericocele), haemorrhoidal plexus (Haemorrhoides), and lower limb (Varicose veins)(2). Varicose veins are clinically characterized by spider veins, oedema, itching of lower limbs, heaviness of limbs, muscle cramps, etc. are embarrasing to the patient(3). As the incidence of etiological factors becomes progressive, advanced clinical appearance observed like lipodermatosclerosis,

\section{* Corresponding Author:}

\section{Kanchan Borkar}

Ph.D scholar,

Department of Shalya Tantra,

Government Ayurveda College,

Nanded. India.

Email Id: drkanchanborkar@gmail.com discoloration, itching, abrasion, ulceration and in this situation, patient suffers and get disturbed from their daily routine activities(4). The management of such condition may be done with different surgical and non surgical modalities in modern science but in Ayurveda, medicinal and parasurgical modes of management of Sirajgranthi i.e varicose veins is mentioned(5)." Snuhi Tail " is helpful in reducing symptoms of varicose veins when applied locally.

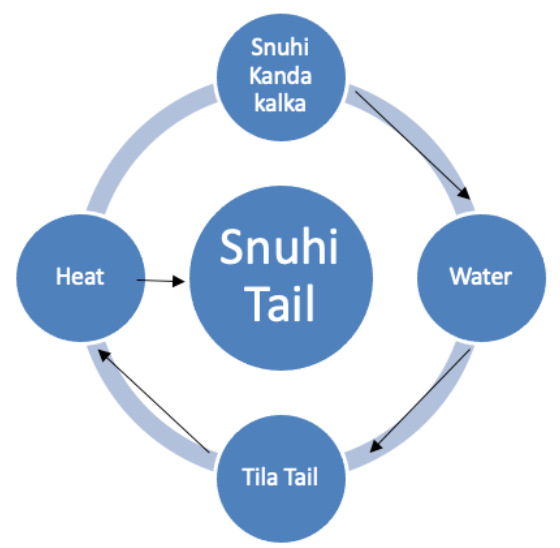

Image 1: Diagram of the preparation of the Snuhi Tail

The raw material used for Snuhi Tail Preparation was obtained from plant Snuhi of species Euphorbia nerifolia L (6). Kanda (Stem) part of Snuhi plant was used. Tila Tail was used as a base for preparation. In the present study Snuhi Tail was prepared three times and standardization of raw material and Snuhi Tail was done each time to set the standard parameters of Snuhi Tail.

\section{Aims and Objectives}

- To prepare Snuhi Tail with Snuhi Kanda (Stem) Kalka and Tila Tail.

- To standardized physic-chemical analysis of Snuhi Tail formulation.

- To establish effective local application in varicose veins. 


\section{Materials and Methods}

\section{Preparation of Snuhi Tail}

Preparation of Snuhi Taila was carried out at Rasashastra dept, Government Ayurveda College, Nanded.

\section{Materials}

Materials required for preparation of Snuhi Tail were mentioned below.

1. Tila Tail

2. Snuhi Kanda (Stem) kalka

3. Water

4. Steel Vessels as container

5. Cutter

6. Mixer Grinder

7. Stirrer

8. Cotton cloth for filtration

9. Air tight plastic bottles of $150 \mathrm{ml}$ capacity for packing and storage

- Snuhi Kanda: It was collected by cutting the part of stem of Snuhi plant (Euphorbia nerifolia L). Collected stem then cut into small pieces so that it could be grind easily to make Kalka.

- Tila Tail: Tila Tail was used as a base form which was bought from market.

- Steel Vessels : It was used to store raw materials like Snuhi Kanda Kalka, water and Tila Tail.

- Cutter: Cutter was used to cut the stem of Snuhi into small pieces so that it can ground easily.

- Mixer Grinder: Mixer grinder was used to grind the cut small pieces of Snuhi Kanda.

- Cotton cloth : It was used to filter the prepared Snuhi Tail after complete evaporation of water content in it.

- Plastic Bottles: Air tight plastic bottles of $150 \mathrm{ml}$ capacity were used to store the oil so that it was become easy to provide for patient.

\section{Method of Snuhi Tail Preparation}

$1 \mathrm{~kg}$ of Snuhi stem (Kanda) kalka, 4 part of Tila Tail (4 liter),16 part of water (16 liter) were mixed in a steel container which was then kept on gas, All above ingredients was then mixed with the help of stirrer, then the mixture was allowed to boil till all water content gets evaporated.

After observing Sneha Siddhi Lakshanas according to Sharangdhar Samhita(7) i.e.

- Varti Pradurbhawa

- Shabdahinata

- Fenodbhavata

The obtained oil was Sample I of Snuhi Tail. After cooling down the temperature of Snuhi Tail it was then packed in $150 \mathrm{ml}$ plastic bottles.

In the Same way other two samples i.e Sample II and Sample III of Snuhi Tail were prepared by same material and methodologies at interval of one year of time.

\section{Precautions}

- No water content should be left behind so that free from fungal development.

- Seal of packed bottles should be kept air tight to avoid leakage of oil.

\section{Observations and Results}

Drug authentication of Snuhi Stem was done for proper selection and confirmation of Snuhi stem i.e. Euphorbia nerifolia L. Drug authentication was done on three samples of Snuhi Stem before each three preparations of Snuhi Tail.

\section{Table 1: Drug authentication}

\begin{tabular}{|c|c|c|c|}
\hline Product Name & Snuhi Stem & Snuhi Stem & Snuhi Stem \\
\hline Batch Number & SS01 & $\mathrm{SS} 02$ & $\mathrm{SS} 03$ \\
\hline $\begin{array}{l}\text { Sample } \\
\text { Quantity }\end{array}$ & $100 \mathrm{gm}$ & $100 \mathrm{gm}$ & $100 \mathrm{gm}$ \\
\hline $\begin{array}{l}\text { Sample } \\
\text { Description }\end{array}$ & $\begin{array}{l}\text { Grayish } \\
\text { Colour Stem }\end{array}$ & $\begin{array}{l}\text { Grayish } \\
\text { Colour Stem }\end{array}$ & $\begin{array}{l}\text { Grayish } \\
\text { Colour Stem }\end{array}$ \\
\hline $\begin{array}{l}\text { Water Soluble } \\
\text { Extract }\end{array}$ & $9.72 \% \mathrm{w} / \mathrm{w}$ & $9.53 \% \mathrm{w} / \mathrm{w}$ & $8.95 \% \mathrm{w} / \mathrm{w}$ \\
\hline $\begin{array}{l}\text { Alcohol } \\
\text { Soluble Extract }\end{array}$ & $4.242 \% \mathrm{w} / \mathrm{w}$ & $4.367 \% \mathrm{w} / \mathrm{w}$ & $4.579 \% \mathrm{w} / \mathrm{w}$ \\
\hline Total Ash & $4.32 \% \mathrm{w} / \mathrm{w}$ & $5.58 \% \mathrm{w} / \mathrm{w}$ & $4.95 \% \mathrm{w} / \mathrm{w}$ \\
\hline Acid- Insoluble & $1.20 \% \mathrm{w} / \mathrm{w}$ & $1.65 \% \mathrm{w} / \mathrm{w}$ & $1.44 \% \mathrm{w} / \mathrm{w}$ \\
\hline
\end{tabular}

Table no. 1. shows that three samples of $100 \mathrm{gm}$ of each sample of stem of Euphorbia nerifolia L was studied for authentication. Physical properties like colour, weight while chemical properties like water soluble extract, alcohol soluble extract, total ash and acid insoluble ash was studied and it was observed that findings and values of physico-chemical properties of three samples are approximately same range.

\section{Physico-Chemical properties (Characteristics) of Snuhi Tail}

$150 \mathrm{ml}$ of prepared snuhi tail was sent for analysis to reputed Pharmacy. Organoleptic characteristics like color, odor, refractive index, acid value, saponification value, iodine value, peroxide value, and total oil content were assessed with standard procedure and obtained results are given in Table no. 2 .

\section{Table 2: Physico-Chemical characteristics of Snuhi Tail}

\begin{tabular}{|c|c|c|c|}
\hline Characteristics & Sample 1 & Sample 2 & Sample 3 \\
\hline Colour & $\begin{array}{l}\text { Greenish to } \\
\text { Yellowish }\end{array}$ & $\begin{array}{l}\text { Greenish to } \\
\text { Yellowish }\end{array}$ & $\begin{array}{l}\text { Greenish to } \\
\text { yellowish }\end{array}$ \\
\hline Odour & $\begin{array}{c}\text { Characteristic } \\
\text { aroma }\end{array}$ & $\begin{array}{c}\text { Characteristic } \\
\text { aroma }\end{array}$ & $\begin{array}{c}\text { Characteristic } \\
\text { aroma }\end{array}$ \\
\hline $\begin{array}{l}\text { Refractive } \\
\text { index }\end{array}$ & 1.5255 & 1.5145 & 1.5347 \\
\hline Acid value & 2.48 & 2.38 & 2.37 \\
\hline $\begin{array}{l}\text { Saponification } \\
\text { value }\end{array}$ & 192.05 & 190.30 & 191.26 \\
\hline Iodine value & 106.155 & 105.20 & 107.189 \\
\hline Peroxide value & 3.57 & 3.50 & 4.12 \\
\hline $\mathrm{wt} / \mathrm{ml}$ & 0.917 & 0.916 & 0.921 \\
\hline Total oil content & $95.75 \%$ & $94.04 \%$ & 96.27 \\
\hline
\end{tabular}

Table no.2. shows that physical properties like colour and odour, weight, while chemical properties like refractive index, acid value, saponification value, iodine value, peroxide value and total oil content of each three Samples were observed within the same range. 


\section{Discussion}

While preparation of Snuhi Tail a skilled and experienced hand was very important to prevent faulty techniques during preparation. After proper collection of Snuhi stem it was necessary to distract its spikes from stem so that it was became easy to handle while cutting the stem into small pieces. If soft or younger stem of Snuhi was used then it was easy to cut and grind but if tough or elder Snuhi stem was used then it was difficult to cut into small pieces and needs some addition of water while grinding. It was also observed that during the process of boiling constant stirring of contents in steel container was needed so that Kalka should not stuck to container. During the process of filtration the residual over cloth should be squeezed properly to avoid loss of oil and to get maximum amount of Snuhi Tail . It was also observed that use of small funnel makes easy to pour the oil into bottle which may help to avoid the loss of oil during packing. After packing, bottles should be store at room temperature.

Tila Tail and Snuhi had been used since many hundreds of years for treating various disorders in Ayurveda as internal or external medication. Sneha Kalpana is unique dosage form that contains both lipid soluble and water soluble medicaments to provide a very broad spectrum therapeutic index for the disease specially in varicose veins. So further study can be done with multiple ingredients with Snuhi to increase the efficacy of oil.

Three samples of oil were prepared by same material and methodologies at interval of one year of time. After complete analysis of three samples, it was observed that these samples show approximately same values of its Physico chemical characteristics. From this analysis it can be said that Snuhi Tail has acceptability, suitability and stability with disease palliative efficacy towards the management of varicose veins as a local application.

\section{Conclusion}

It was observed that analytical reports of the standardizing parameters like specific gravity, refractive Index, acid value, saponification value, iodine values of all the samples were approximately shows $\pm 10 \%$ variations .Hence tendency to rancidity, efficacy and shelf life of three samples are nearly same. It was observed that Snuhi Tail remains stable with same quality and parameters at room temperature and relative humdity. The data generated was documented and may provide scope for further research in this regards with more advanced tools and technology to form potent Ayurvedic Sneha Kalpana i.e. Snuhi Tail . So it can be concluded that, it is the standard procedure for preparation of Snuhi Tail which can be used as local application to maintain patient's comfort in varicose vein.

\section{References}

1. Bailey and Love's short practice of surgery, Arnold, International student's publication, 23 rd. Edition, pg. no. 235 .

2. SRB's Manual of surgery, Sriram Bhatt M,Jaypee brothers pvt.ltd, 3'rd edition 2009, pg. no 196.

3. A concise text book of surgery ; S.Das ; S. Das publication, Calcutta, 4th edition, 1999 pg.no 200-208.

4. Risk factors of varicose vein by Tiina Ahit, Faculty of medicine of Tampere university, Tampere, March 26th 2010, pg. no 34.

5. Sushruta Vimarshini, Hindi vyakhya, Anantram Sharma,vol-2, Chaukhamba Surbharati Prakashana, Varanasi, 2113, pg. no 205.

6. Bhavprakash Nighantu, Shri Bhramhashankar Shastri, Vidyotini hindi vyakhya, poorvardha, Chaukhamba Sanskrit Sansthan, Varanasi, 1st edition, Page no.308.

7. Sharangadhara Samhita, Bramhanand Tripathi, Chaukhamba Surbharati Prakashana, Varanasi, 1st edition 1990, 9th adhyaya, pg. no. 244.

\section{Images}

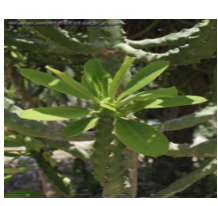

Image 2:

Euphorbia nerifolia $L$

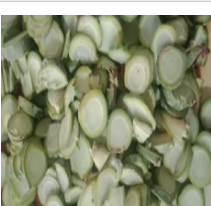

Image 3:

Chopped

Pieces of

Snuhi Stem

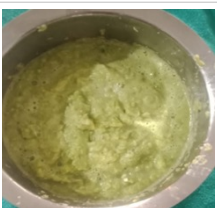

Image 4:

Snuhi Kalka

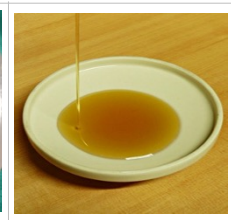

Image 5:

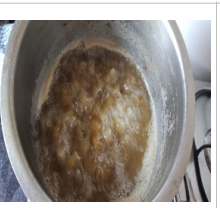

Image 6:

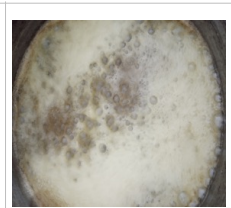

Image 7:

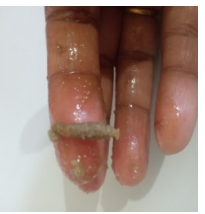

Image 8:

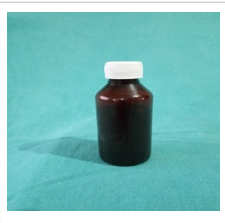

Image 9:

Varti

Bioling Fennodbhava Pradurbhava

Packing 